\title{
Duration of Greenland Stadial 22 and ice-gas $\Delta$ age from counting of annual layers in Greenland NGRIP ice core
}

\author{
P. Vallelonga ${ }^{1}$, G. Bertagna ${ }^{1}$, T. Blunier ${ }^{1}$, H. A. Kjær ${ }^{1}$, T. J. Popp ${ }^{1}$, S. O. Rasmussen ${ }^{1}$, J. P. Steffensen ${ }^{1}$, C. Stowasser ${ }^{1}$, \\ A. S. Svensson ${ }^{1}$, E. Warming ${ }^{1}$, M. Winstrup ${ }^{1}$, M. Bigler ${ }^{2}$, and S. Kipfstuhl ${ }^{3}$ \\ ${ }^{1}$ Centre for Ice and Climate - Niels Bohr Institute, University of Copenhagen, Juliane Maries Vej 30, \\ 2100 Copenhagen $\varnothing$, Denmark \\ ${ }^{2}$ Physics Institute, Climate and Environmental Physics and Oeschger Centre for Climate Change Research, \\ University of Bern, Sidlerstrasse 5, 3012 Bern, Switzerland \\ ${ }^{3}$ Alfred Wegener Institute, Glaciology, Colombusstrasse, 27568 Bremerhaven, Germany
}

Correspondence to: P. Vallelonga (ptravis@nbi.ku.dk)

Received: 23 June 2012 - Published in Clim. Past Discuss.: 16 July 2012

Revised: 31 October 2012 - Accepted: 8 November 2012 - Published: 20 November 2012

\begin{abstract}
High-resolution measurements of chemical impurities and methane concentrations in Greenland ice core samples from the early glacial period allow the extension of annual-layer counted chronologies and the improvement of gas age-ice age difference ( $\Delta$ age) essential to the synchronization of ice core records. We report high-resolution measurements of a $50 \mathrm{~m}$ section of the NorthGRIP ice core and corresponding annual layer thicknesses in order to constrain the duration of the Greenland Stadial 22 (GS-22) between Greenland Interstadials (GIs) 21 and 22, for which inconsistent durations and ages have been reported from Greenland and Antarctic ice core records as well as European speleothems. Depending on the chronology used, GS22 occurred between approximately 89 (end of GI-22) and $83 \mathrm{kyr}$ b2k (onset of GI-21). From annual layer counting, we find that GS-22 lasted between 2696 and 3092 years and was followed by a GI-21 pre-cursor event lasting between 331 and 369 yr. Our layer-based counting agrees with the duration of stadial 22 as determined from the NALPS speleothem record $(3250 \pm 526 \mathrm{yr})$ but not with that of the GICC05modelext chronology (2620 yr) or an alternative chronology based on gas-marker synchronization to EPICA Dronning Maud Land ice core. These results show that GICC05modelext overestimates accumulation and/or underestimates thinning in this early part of the last glacial period. We also revise the possible ranges of NorthGRIP $\Delta$ depth (5.49 to $5.85 \mathrm{~m}$ ) and $\Delta$ age (498 to $601 \mathrm{yr}$ ) at the warming onset of GI-21 as well as the $\Delta$ age range at the onset of
\end{abstract}

the GI-21 precursor warming ( 523 to $654 \mathrm{yr}$ ), observing that temperature (represented by the $\delta^{15} \mathrm{~N}$ proxy) increases before $\mathrm{CH}_{4}$ concentration by no more than a few decades.

\section{Introduction}

Ice core records are of great importance to paleoclimate studies due to their ability to archive several climate parameters in continuous, precisely dateable stratigraphic sequences. The year-round regularity and relatively high accumulation rate of snowfall in central Greenland has allowed determination of annual cycles in stable water isotopes, ions and dust back to $60 \mathrm{kyr}$ before $2000 \mathrm{AD}$ (b2k) (Svensson et al., 2008). Synchronization between ice core records is undertaken using a number of hemispheric or globally homogeneous signals, such as gases (e.g. Bender et al., 1994; Blunier and Brook, 2001; EPICA community members, 2006), their isotopic signatures (e.g. Severinghaus et al., 1998; Capron et al., 2010b) or large volcanic eruptions (e.g. Rasmussen et al., 2008; Parrenin et al., 2012). Inverse methods have been employed to produce consistent ice core chronologies combining relative and absolute chronological markers in several synchronized ice core records (Lemieux-Dudon et al., 2010).

The Greenland Ice Core Chronology 2005 (GICC05), of which the most recent extension is GICC05modelext, is based on counting of annual strata in ice cores back to $60 \mathrm{kyr}$ b2k. This common chronology for multiple Greenland 
ice cores employs annual layer counting of stable water isotopes from the surface to $7.9 \mathrm{kyr} b 2 \mathrm{k}$, annual layer counting of impurities and visual stratigraphy (greyscale images related to microparticle density) strata back to $60 \mathrm{~b} 2 \mathrm{k}$ (Svensson et al., 2005, 2008), and an ice-flow model (ss09sea06 bm) chronology back to $123 \mathrm{kyr}$ b2k (Johnsen et al., 2001; Wolff et al., 2010). GICC05modelext offers the paleoscience community a chronological framework for the duration of the Holocene as well as the last glacial period, for which 25 stadial-interstadial oscillations have been identified based on the oxygen isotope ratio in ice $\left(\delta^{18} \mathrm{O}_{\text {ice }}\right)$ (NGRIP members, 2004).

The use of Greenland Interstadial (GI) and Greenland Stadial (GS) nomenclature is an attempt to standardize the description of Greenland millennial-scale temperature oscillations first known as Dansgaard-Oeschger (DO) events. The first numbering of DO events employed low-resolution $\delta^{18} \mathrm{O}_{\text {ice }}$ record from the GRIP ice core, which failed to capture rapid, small-scale temperature changes now described as "precursor" and "rebound" events (Capron et al., 2010a). The assignment of precursor events to either the GI following or GS preceding has not yet been standardized, and hence can contribute to the discrepancies between the durations calculated for GS-22; it is important that authors specify whether they include or exclude precursor events from their evaluations of stadial durations. For example, Capron et al. (2010a) evaluated the duration of GS-22 from the mid-point of the $\delta^{18} \mathrm{O}_{\text {ice }}$ transition at the end of GI-22, to the initial increase of $\delta^{18} \mathrm{O}_{\text {ice }}$ at the onset of the GI-21 precursor event. In this work, we follow the same approach for evaluating the duration of GS-22. Where possible, we describe durations for both GS-22 and the GI-21 precursor period, which we define here as the duration from the onset of precursor warming (i.e., the end of GS-22 proper) to the mid-point of the $\delta^{18} \mathrm{O}_{\text {ice }}$ transition in the subsequent GI- 21 onset. With the recent development of high-resolution techniques for analysis of water isotopologues (Gkinis et al., 2011), impurities (Bigler et al., 2011) and methane content (Stowasser et al., 2012) in ice cores, a systematic nomenclature for identifying stadial and interstadial events and their substructure is clearly required.

A recent Antarctic ice core chronology has led to discrepancies in the duration of GS-22, suggesting that the current model-based duration is underestimated. GICC05modelext indicates a GS-22 duration of $2620 \mathrm{yr}$, from 87680 to $85060 \mathrm{yr} \mathrm{b2k}$, with a GI-21 precursor duration of $300 \mathrm{yr}$ (Wolff et al., 2010). Capron et al. (2010b) investigated the duration of Antarctic temperature oscillations in the EPICA Dronning Maud Land (EDML) ice core over the same time period and observed that the Antarctic Isotope Maxima that correspond to each set of Greenland stadial-interstadials (Fig. 1), which are characteristic of the thermal bipolar seesaw, were misaligned for GS-22. Aligning the EDML and NorthGRIP (NGRIP) ice core records by measurements of oxygen isotope ratios in $\mathrm{O}_{2}\left(\delta^{18} \mathrm{O}_{\text {atm }}\right)$ and $\mathrm{CH}_{4}$ concentrations in the air trapped in the ice, they calculated an EDML-

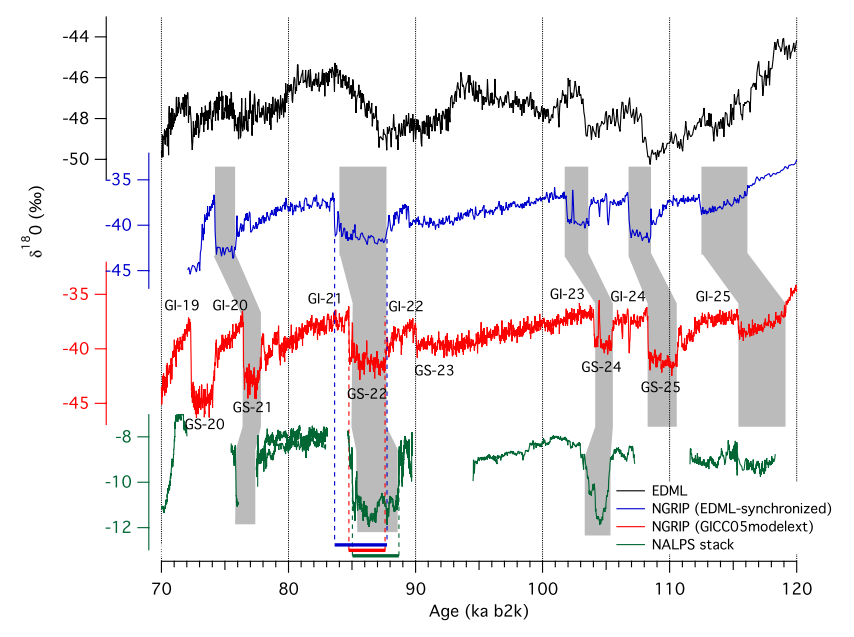

Fig. 1. Comparison of temperature proxy records from Greenland, Europe and Antarctica. The Antarctic EPICA Dronning Maud Land (EDML) ice core $\delta^{18} \mathrm{O}_{\text {ice }}$ record is shown in black (EPICA community members, 2006). The Greenland NorthGRIP ice core $\delta^{18} \mathrm{O}_{\text {ice }}$ record is shown in blue (NGRIP-EDML gas-synchronized chronology, Capron et al., 2010b) and red (GICC05modelext chronology, Wolff et al., 2010). The Northern Alps (NALPS) speleothem record is shown in green (Boch et al., 2011). Colored markers at the bottom of the graph show the different timings and durations of GS-22 according to each archive and chronology.

based duration for GS-22 and found that the proposed duration of GS-22 (and warming of the consequent Antarctic Isotope Maxima, AIM21) was discrepant with the linear relationship between GS duration and Antarctic warming proposed by EPICA community members (2006).

The most recent indication of an underestimation of the duration of GS-22 in GICC05modelext is based on radiometrically-dated speleothems from the Northern Alps (Boch et al., 2011). Oxygen isotopes were used to identify the cold and warm stages that correspond to the Greenland stadials and interstadials in the NALPS speleothem record, which were compared to GICC05modelext. Based on the speleothem record, the duration of stadial 22 was $3250 \pm 526(2 \sigma)$ yr. While interhemispheric ice core records can be synchronized by gas tie points, additional considerations have to be taken into account for the synchronization of speleothems and ice cores. For example, stalagmite records are also available from regions other than the Alps, covering the period of interest of this study, but we hesitate to compare those records directly to Greenland because they may not reflect exactly the same climate signature as the North Atlantic records. For instance, the Chinese Saobao stalagmites (Wang et al., 2008) are dominated by the East Asian Monsoon and show a reversed isotopic signal compared to that of the North Atlantic region. At the decade-to-centennial resolution we are concerned with here, there are no strong arguments to assume comparable event durations between those Greenland and Chinese records. In cases where speleothems 
and ice cores do respond comparably to the same climate forcings, the calculated duration of the stadial can be different due to the different criteria that may be applied to define event boundaries. In the case of such definition criteria, we assume that these effects influence the duration estimate by an amount significantly smaller than the duration uncertainties. High-resolution analytical techniques allow the generation of an annual-layer counted chronology that can help to resolve the discrepancies described here.

Continuous flow analysis (CFA) techniques have been developed to improve the reliability and resolution of measurements of ice core impurities (e.g. Röthlisberger et al., 2000; Kaufmann et al., 2008; Bigler et al., 2011). For most analytes, they are replacing the traditional ion chromatographic technique and offering the potential for coupling to online measurements of methane (Stowasser et al., 2012) and water isotopologues (Gkinis et al., 2010). The improved resolution of CFA allows the possibility of direct determinations of annual layer thicknesses in Greenland ice back to the inception of the last glacial climate period (Svensson et al., 2011). Techniques for determination of various climate parameters at high resolution have also been applied to the study of timing and duration of various climate proxies during glacial (Steffensen et al., 2008) and GS terminations (Thomas et al., 2009).

Here we revise the duration of GS-22, based on the highresolution measurement of insoluble dust particles, ionic impurities and visual stratigraphy in the NGRIP ice core. This technique offers the resolution of annual layers of $<1 \mathrm{~cm}$ (Bigler et al., 2011), sufficient for the counting of annual layers during GS-22 and adjacent GIs. Combined with continuous measurements of $\mathrm{CH}_{4}$ concentrations, we refine the ice depth-gas depth ( $\Delta$ depth) and gas age-ice age difference $(\Delta$ age $)$ differences at this depth of the NGRIP record. This technique opens the potential for further refinement of GICC05modelext by evaluating annual layers and rapid gas transitions in the deepest sections of Greenland ice cores and synchronizing them with corresponding transitions in Antarctic ice cores.

\section{Experimental}

\subsection{Ice core samples}

Samples were obtained from the NorthGRIP ice core drilled in Northwest Greenland between 1997 and 2004 (NGRIP members, 2004). The samples correspond to the depth range $2679.05-2729.65 \mathrm{~m}$ of which only two $55 \mathrm{~cm}$ sections were unavailable (depths 2682.45-2682.90 and 2684.00$2684.55 \mathrm{~m}$ ). A $35 \times 35 \mathrm{~mm}$ section was cut for CFA analysis from the remaining "archive" piece. Optical line-scan images of the full ice core cross-section were collected at the drilling site (Svensson et al., 2005). $\delta^{18} \mathrm{O}$ data were used to evaluate GS and GI events in the NGRIP (Wolff et al., 2010) and NALPS (Boch et al., 2011) records. As mentioned previously, we define GS-22 here as the cold Greenland stadial period occurring from the mid-point of the $\delta^{18} \mathrm{O}$ transition at the end of GI-22, to the onset of the warming ( $\delta^{18} \mathrm{O}$ increase) of the GI-21 precursor event.

\subsection{Measurements}

The CFA system used for the measurements has been described by Bigler et al. (2011) and will be summarized here. The samples were melted on an aluminium melthead with a square inner sampling section $(26 \mathrm{~mm} \times 26 \mathrm{~mm})$. A constant ice melting rate of $1.5 \mathrm{~cm} \mathrm{~min}^{-1}$ produced meltwater at a rate of $8.4 \mathrm{~mL} \mathrm{~min}^{-1}$, of which $6 \mathrm{~mL}$ was directed to the analytical channels. The remaining $2.4 \mathrm{~mL} \mathrm{~min}^{-1}$ was used to flush a sealed debubbler to ensure effective removal of air from the CFA analytical channels. The overflow air was delivered to a cavity ring-down spectrometer (Picarro Inc., CFADS36 $\mathrm{CO}_{2} / \mathrm{CH}_{4} / \mathrm{H}_{2} \mathrm{O}$ analyzer) for continuous measurements of methane concentrations (Stowasser et al., 2012). The debubbled meltwater was distributed to various analytical channels where continuous measurements of insoluble dust particles ( $>1.0 \mu \mathrm{m}$ diameter), electrolytic conductivity, sodium and ammonium were conducted.

\subsection{Layer-counting technique}

The technique used for layer counting is identical to the one used for the glacial part of GICC05modelext (Svensson et al., 2008). The parameters used for assignment of annual cycles included visual stratigraphy, electrolytic conductivity and insoluble dust particle concentration. Annual layers in sodium were not observed due to diffusion in the ice as well as the limited sampling resolution of $\sim 3.5 \mathrm{~mm}$ for this analyte, compared to $\sim 1.5 \mathrm{~mm}$ for electrolytic conductivity and $\sim 3 \mathrm{~mm}$ for ammonium. Annual cycles in ammonium were identifiable only during the interstadials, when greater concentrations and thicker layers enabled their identification. It is worth noting that the two ions determined here have diffused to differing extents although the total electrolytic conductivity still shows reliable annual cycles. This suggests that other ions dominate the electrolytic conductivity of ice core meltwater, for example Moore et al. (1994) noted that acid species are most important for DC conductivity in solid ice whereas ammonium salts and probably chloride are also important for AC conductivity. Three people independently evaluated the data to produce three annual layer counting results. Where an annual layer was uncertain, it was assigned a value of $\frac{1}{2} \pm \frac{1}{2} \mathrm{yr}$. The three independent counting results were then evaluated again to produce a consistent final counting result. The maximum counting error (MCE) was calculated as the sum of the "uncertain" annual layers, and can be considered equivalent to a $2 \sigma$ uncertainty interval (Andersen et al., 2006). For the sections where ice was not available to measure, the layer thickness has been linearly interpolated 
from the adjacent measured sections. A section of NGRIP ice demonstrating the assignment of annual layers is shown in Fig. 2.

\section{Results}

Concentrations of ice core impurities determined by highresolution CFA were consistent with previously reported values for sodium, ammonium and conductivity in Greenland glacial ice (Bigler, 2004). We have determined average GS-22 (NGRIP depths 2687.5-2718 m) values of $8.6 \mathrm{ppb}$ for ammonium, $70 \mathrm{ppb}$ for sodium, $1.0 \mu \mathrm{S} \mathrm{cm}^{-1}$ for electrolytic conductivity and $56 \times 10^{3}$ insoluble dust particles $>1.0 \mu \mathrm{mLL}^{-1}$. While an impurity record for the whole NGRIP ice core is still in preparation, the results reported here are consistent with available records from GISP2 ice core (Mayewski et al., 1997) and NGRIP (Andersen et al., 2006; Ruth et al., 2002). From Fig. 2 it can be observed that diffusion has broadened the signals of sodium and ammonium such that annual layers cannot be identified based on these records at this depth in NGRIP. In the sections corresponding to warmer GI-21 and GI-22, thicker annual ice layers as well as greater concentrations of ammonium allowed the detection of annual peaks in this record.

Annual layer thicknesses $(\lambda)$ were primarily determined from peaks in electrolytic conductivity, insoluble dust particles and visual stratigraphy. Figure 3 shows $\lambda$-values reported here as well as those calculated by ss09sea06bm. The annual-layer counted $\lambda$-values were consistently smaller than those calculated by the flow model. We assigned the onset and end of GS-22 as, respectively, depths 2718.0 and $2691.1 \mathrm{~m}, \delta^{18} \mathrm{O}$-values -40.12 and -39.82 and GICC05modelext ages of 87680 and $85060 \mathrm{kyr}$ b2k. Based on the annual-layer counting reported here, the duration of GS-22 was not less than 2696 and not more than $3092 \mathrm{yr}$. These results are summarized in Table 1 and compared to previously reported durations for GS-22 and the GI21 precursor period.

\section{Discussion}

\subsection{Implications for Greenland ice core chronologies}

The GS-22 duration range presented here (2696-3092 yr) is inconsistent with that of GICC05modelext (2620 yr) and indicates an overestimation of annual layer thickness in this part of the NGRIP ice core. GICC05modelext is constrained in the upper section by annual layer counting, but is essentially unconstrained for the lowest $650 \mathrm{~m}$ of ice. Beyond the $60 \mathrm{kyr}$ limit of annual-layer counted strata, no independent chronological markers are currently available. Other lines of evidence exist to suggest that annual layer thicknesses are overestimated by the ss 09 sea $06 \mathrm{bm}$ ice flow model. Firn densification models used to reconstruct NGRIP temperatures

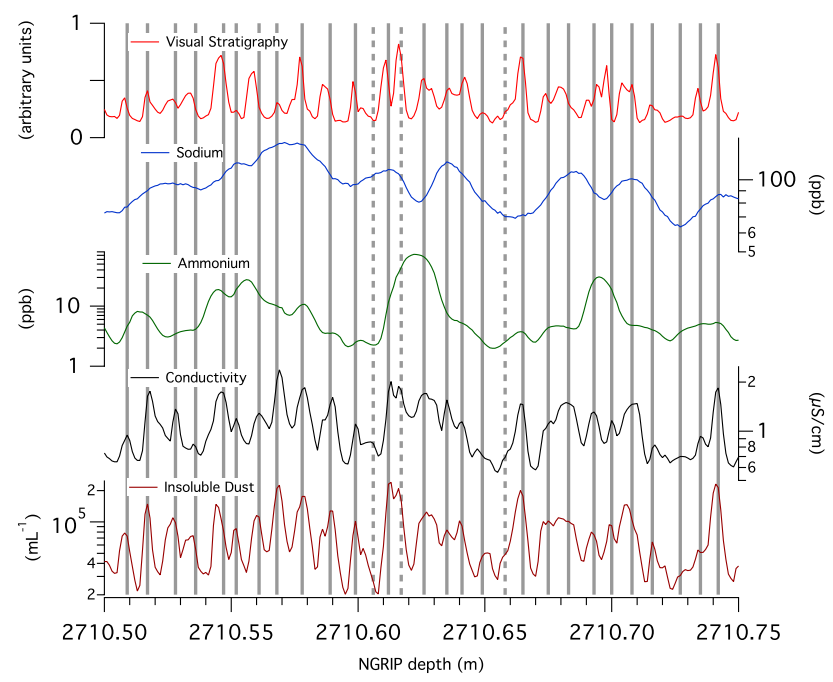

Fig. 2. Example of Continuous Flow Analysis (CFA) measurements of NorthGRIP glacial ice and assignment of annual layers. Visual stratigraphy was measured by optical scanning at the drilling site, not by CFA. Vertical gray bars indicate "certain" (solid line) and "uncertain" (dotted line) years. Note that sodium, ammonium, conductivity and insoluble dust are plotted on logarithmic scales.

from $\delta^{15} \mathrm{~N}$ measurements required annual snow accumulation rates to be decreased by $20 \%$ to produce a consistent result for GIs 9-17 (Huber et al., 2006); and annual layer counting of NGRIP Eemian and early glacial ice (Svensson et al., 2011) also suggest $\lambda$ is partly overestimated in the deeper sections of NGRIP. Annual layer thicknesses are essentially dictated by two parameters - snow accumulation and vertical strain - thus an inaccurate evaluation of either parameter will contribute to an overall bias in $\lambda$. These findings indicate that GICC05modelext requires revision for the durations of GS-22 and probably also GI-21 and GI-22. To see if other deep sections of NGRIP are also affected by an inaccurate calculation of $\lambda$, we compare the record to an independent paleoclimate archive.

A number of precisely-dated speleothem records have recently been reported, allowing the possibility of comparing mid- and low-latitude climate variations to those recorded in the Greenland ice core records. Boch et al. (2011) reported a climate record of the northern alpine region of Europe, NALPS, produced from a stack of speleothems dated by high-resolution U-Th measurements. Although there are gaps in the record, it can be seen in Fig. 1 that NALPS replicates some of the DO oscillations observed in NGRIP ice, particularly the transitions at the onset and end of GS-21 (approximately $77 \mathrm{kyr}$ ago) and the entirety of GS-23 (approximately $105 \mathrm{kyr}$ ago). As demonstrated by Boch et al. (2011) the GICC05modelext and NALPS chronologies are in agreement within their uncertainties for most of the early glacial period between 77 and $115 \mathrm{kyr}$. The two chronologies are discrepant between 78 and $103 \mathrm{kyr}$, for which differences 


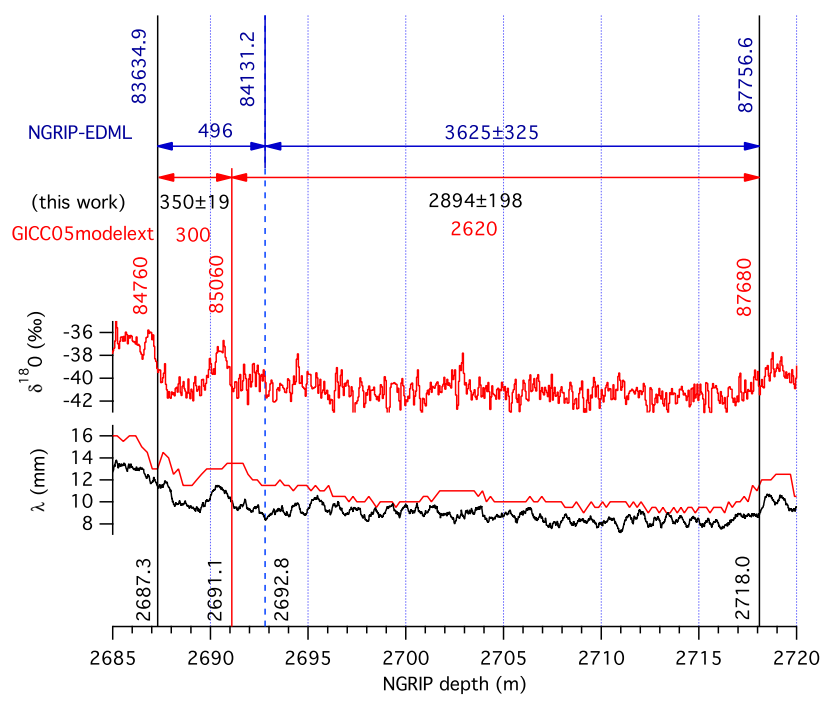

Fig. 3. Comparison of NorthGRIP ice core chronologies over the interval between GI-21 and GI-22. Also shown are NGRIP $\delta{ }^{18} \mathrm{O}_{\text {ice }}$ and annual layer thicknesses $(\lambda)$ from the $s 509$ sea06bm ice-flow model and from annual layer counting (this study). Numbers shown horizontally correspond to event durations in years calculated from GICC05modelext in red (Wolff et al., 2010), NGRIP-EDML gassynchronized chronology in blue (Capron et al., 2010b) and annual layer counting in black (this study). Vertical numbers show NGRIP depths (black) corresponding to absolute ages in years before $2000 \mathrm{AD}$ from GICC05modelext (red) and EDML-synchronized NGRIP (blue) chronologies.

of $445 \mathrm{yr}$ (GI-23 onset) and $1010 \mathrm{yr}$ (GS-22 onset) were reported. As we demonstrate that GICCO5modelext underestimates the duration of GS-22, we can thus conclude that the chronology also overestimates the duration of GI-22/GS23/GI-23, otherwise it would not be consistent with the NALPS chronology for the early glacial period prior to GI23. If GICCO5modelext overestimates the snow accumulation rate at NGRIP - consistent with the findings of Huber et al. (2006) - it would possibly explain why there are too many years assigned to the GI-22/GS-23/GI-23 period, but it would not explain why too few years have been assigned to GS-22. The findings presented here offer a reliable dataset for tuning the ss09sea06bm model upon which GICC05modelext is based. In the absence of further constraints, we note that the overall assumptions underlying ss09sea06bm are robust. At $60 \mathrm{kyr}$ b2k, there was only a $705 \mathrm{yr}$ discrepancy between the model and the layer-counted GICC05 age scale (Wolff et al., 2010). An uncertainty budget has not been reported for ss09sea06bm so the model can only be validated by comparison to independent dating efforts such as that presented here.

\subsection{Implications for Antarctic ice core synchronization}

Constraints to GICC05modelext have also been proposed using isotopic markers and gas-based synchronization to the well-resolved EPICA Dronning Maud Land (EDML) ice core. Capron et al. (2010b) reported $\mathrm{CH}_{4}$ concentrations, $\delta^{15} \mathrm{~N}$ and $\delta^{18} \mathrm{O}_{\text {atm-values in NGRIP and EDML ice, using }}$ these proxies to apply the EDML chronology to the deepest sections of NGRIP. Both $\mathrm{CH}_{4}$ and $\delta^{18} \mathrm{O}_{\text {atm }}$ are globally homogenous on decadal timescales while $\delta^{15} \mathrm{~N}$ has been demonstrated to respond to changes in the firn column temperature and thickness and thus can be employed to identify rapid warming events such as the onsets of GIs (Capron et al., 2010b). $\mathrm{CH}_{4}$ and $\delta^{18} \mathrm{O}_{\text {atm }}$ allow accurate synchronization between ice core gas records but uncertainties are introduced when transferring between gas and ice ages, denoted as $\Delta$ age, for each ice core. Various models have been proposed to account for firn-column diffusion processes (Salamatin et al., 2009) and it has recently been reported that impurity content also plays a significant role in firn densification processes (Hörhold et al., 2012).

Synchronization of ice cores through gas tracers is most precise when both records feature a small $\Delta$ age, and hence high snow accumulation rate and temperature, such as at NGRIP and EDML. Earlier attempts to synchronize NGRIP with Vostok ice core experienced substantial difficulty due to the large $\Delta$ age (up to $5000 \mathrm{yr}$ ) associated with the lowaccumulation site of Vostok (Landais et al., 2006). While gas tracers allow ice core records to be synchronized, they do not guarantee the accuracy of the ice-age chronology. Thus a well-synchronized tie point should not be confused with a well-dated tie point. Transferring a chronology from one ice core to another involves three operations each with their uncertainties. These operations are the $\Delta$ age conversion of the original timescale, then the synchronization of gas tracer tie points, then the $\Delta$ age conversion in the synchronized record. We show here that the uncertainties involved in the transfer of the EDML chronology to GICCO5modelext, in the case of GS-22, likely resulted in a less-accurate timescale than that which existed before.

The EDML-synchronized NGRIP chronology reported by Capron et al. (2010b), hereafter referred to as NGRIP-EDML, suggests a GS-22 duration at least $200 \mathrm{yr}$ greater than the maximum duration determined here. The NGRIP-EDML duration $(3625 \pm 325 \mathrm{yr})$ is greater than all other estimates for GS-22 shown in Table 1, and is only consistent with the upper limit of the NALPS-based duration of $3250 \pm 263 \mathrm{yr}$. Regarding the absolute ages, NGRIP-EDML and GICC05modelext agree on the onset of GS-22 (respectively $87756 \pm 230 \mathrm{yr}$ b2k and $87680 \mathrm{yr} \mathrm{b2k)}$ although the two chronologies are discrepant by 1 kyr by the onset of GI-21. Interestingly, NALPS and GICCO5modelext agree on the absolute age of the onset of GI-21 (respectively $85030 \pm 410$ and $84760 \mathrm{yr}$ b2k) although the two chronologies are discrepant by $0.4 \mathrm{kyr}$ at the onset of GS-22. Now that the NALPS chronology is available as an independent age-control, it appears that the NGRIP$E D M L$ synchronization produced an erroneously large duration for GS-22 by a combination of two factors. Firstly, the GS-22 onset was not shifted to an earlier age as would 
Table 1. Summary of absolute ages of onset and end transitions associated with GS-22, and calculated durations from various NorthGRIP ice core chronologies as well as the NALPS speleothem record.

\begin{tabular}{|c|c|c|c|c|c|c|c|c|}
\hline Chronology & GI-21 onset $^{\mathrm{a}}$ & $\pm 1 \sigma$ & GI-21 precursor onset ${ }^{\mathrm{a}}$ & $\pm 1 \sigma$ & GS-22 onset $^{\mathrm{a}}$ & $\pm 1 \sigma$ & GS-22 Duration ${ }^{a}$ & $\pm 1 \sigma$ \\
\hline GICC05modelext ${ }^{\mathrm{b}}$ & 84760 & & 85060 & & 87680 & & 2620 & \\
\hline $\begin{array}{l}N G R I P-E D M L^{\mathrm{c}} \\
\text { (this work) }\end{array}$ & 83634 & 230 & 84131 & 230 & 87756 & 230 & $\begin{array}{l}3625 \\
2894\end{array}$ & $\begin{array}{r}325^{\mathrm{d}} \\
99^{\mathrm{e}}\end{array}$ \\
\hline$N A L P S^{\mathrm{f}}$ & 85030 & $205^{\mathrm{g}}$ & 85440 & $205^{\mathrm{g}}$ & 88690 & $165^{\mathrm{g}}$ & 3250 & $263^{d}$ \\
\hline
\end{tabular}

${ }^{a}$ Definitions of onsets, ends and durations of Greenland Interstadial (GI) and Greenland Stadial (GS) events are given in the text. ${ }^{\mathrm{b}}$ From Wolff et al. (2010). ${ }^{\mathrm{c}}$ From Capron et al. (2010b). ${ }^{\mathrm{d}}$ Uncertainties are calculated as root-sum-of-squares of the GI precursor and GS onset uncertainties. ${ }^{\mathrm{e}}$ Uncertainty shown here is half of the maximum counting error (MCE) which can be considered equivalent to a $1 \sigma$ uncertainty $\left(1 \sigma=\frac{1}{2} \times\right.$ MCE). MCE is described in the text. ${ }^{\mathrm{f}}$ From Boch et al. $(2011)$. ${ }^{\mathrm{g}}$ Uncertainties reported as $2 \sigma$ (Boch et al., 2011) are shown here as $1 \sigma$ for consistency.

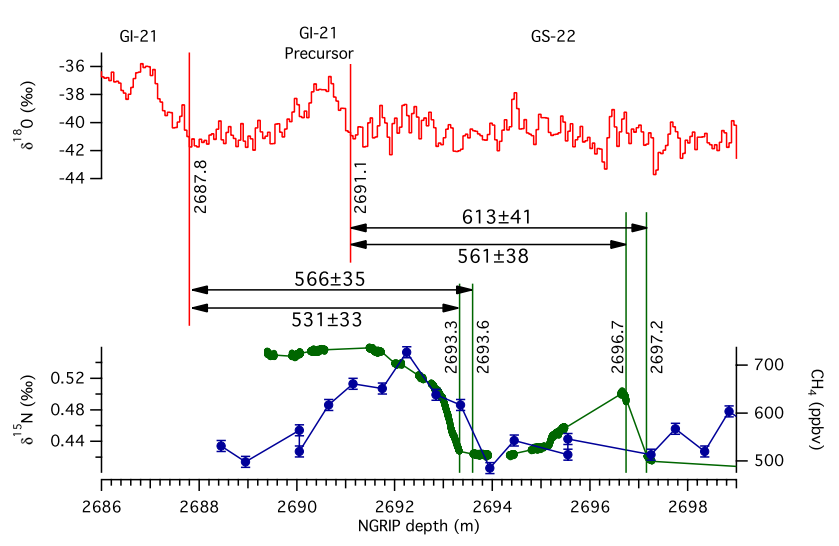

Fig. 4. Comparison of NorthGRIP ice core $\delta^{18} \mathrm{O}_{\text {ice }}$ and trapped gas species for the determination of $\Delta$ age. $\delta^{18} \mathrm{O}_{\text {ice }}$ is shown in red GICC05modelext chronology, Wolff et al., 2010) while $\delta^{15} \mathrm{~N}$ is shown in blue (Capron et al., 2010b) and $\mathrm{CH}_{4}$ concentration is shown in green (this study). Horizontal numbers indicate age differences between ice (red) and gas (green) transitions, while vertical numbers specify the depths assigned to temperature and gas features.

be expected for consistency with NALPS, and secondly, the GI-21 onset was shifted by $900 \mathrm{yr}$ to a later age that is now inconsistent with NALPS. We will attempt to explain the basis for these two factors. The first appears to result from the uncertainties associated with the gas tie points used for the synchronization, whereas the second suggests an inaccuracy in this part of the EDML chronology.

We note that different gas tracers with different uncertainties were used for the synchronization of EDML and NGRIP at the onset and termination of GS-22. Two $\delta^{18} \mathrm{O}_{\mathrm{atm}}$ tie points were used at the onset of GS-22, whereas one $\delta^{15} \mathrm{~N} / \mathrm{CH}_{4}$ tie point was applied at the termination of GS-22. The $\delta^{18} \mathrm{O}_{\text {atm }}$ tie points used to fix the EDML ages of 84577 and $87627 \mathrm{yr}$ BP to NGRIP each carry large uncertainties (respectively 1220 and $570 \mathrm{yr}$ ) - much larger than the differences between GICC05modelext and NGRIP-EDML at that age. On the basis of such poorly constrained tie points, there would be no need to adjust GICC05modelext to fit the ex-

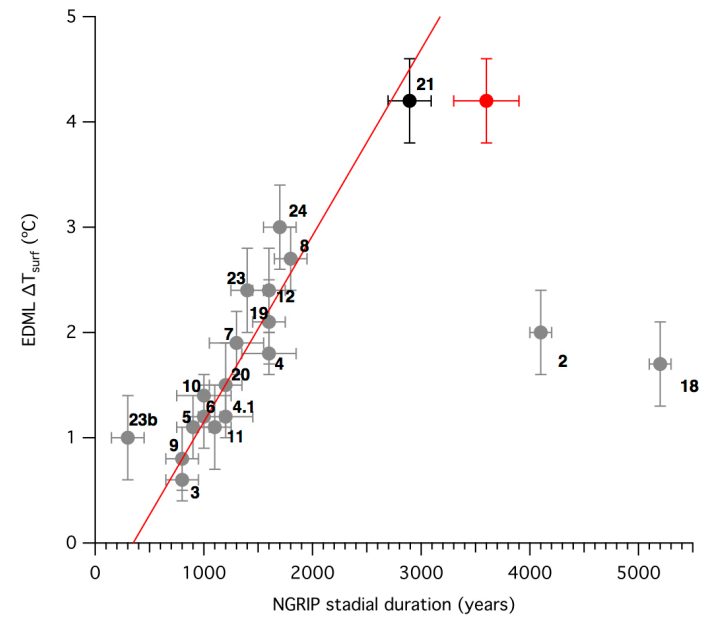

Fig. 5. Comparison of NGRIP stadial duration and EDML temperature change, modified from Capron et al. (2010a). Numbers indicate corresponding GI and AIM events, where the stadial duration is determined from the GS prior to the numbered GI. The durations of GS-22 (together with GI-21 corresponding to AIM21 in the figure) are shown for both EDML-synchronized (red, Capron et al., 2010b) and annual-layer counted (black, this study) NGRIP chronologies.

isting EDML chronology. The opposite case applies for the $\delta^{15} \mathrm{~N} / \mathrm{CH}_{4}$ tie point used at the termination of GS-22, which has a small uncertainty $(150 \mathrm{yr})$ and hence requires that the corresponding depth at NGRIP be fixed to the corresponding age of EDML, $83628 \mathrm{yr}$ b2k. In order to account for the wellconstrained gas tie point at the GI-21 onset, the discrepancy in the resulting NGRIP-EDML chronology must result from inaccurate calculation of the $\Delta$ ages and/or inaccuracies in the EDML chronology. We demonstrate below that Capron et al. (2010b) applied an accurate estimate of the NGRIP $\Delta$ age (approximately $500 \mathrm{yr}$ at the GI-21 onset) and hence the inconsistency in NGRIP-EDML must originate in either the $\triangle$ age or absolute dating of this part of the EDML record.

The NGRIP $\Delta$ age at the GI-21 onset can be constrained using $\mathrm{CH}_{4}$ and $\delta^{15} \mathrm{~N}$ data and the annual-layer counted data reported here. In Fig. 4, we show $\mathrm{CH}_{4}$ concentrations determined in high-resolution as well as the $\delta^{15} \mathrm{~N}$-values reported 
by Capron et al. (2010b). Due to solubility effects in the extraction lines the online $\mathrm{CH}_{4}$ data was calibrated using contemporary values reported in the GISP2 ice core (Grachev et al., 2007). The start of the $\delta^{18} \mathrm{O}_{\text {ice }}$ increase at the onset of the GI-21 was found at an NGRIP depth of $2687.8 \mathrm{~m}$ whereas the start of the associated $\mathrm{CH}_{4}$ concentration increase can be attributed to the range 2693.3-2693.6 m (a gap in the $\mathrm{CH}_{4}$ record precludes a more precise depth evaluation). This corresponds to a $\Delta$ depth range of 5.49 to $5.85 \mathrm{~m}$ and $\Delta$ age range of 498 to $601 \mathrm{yr}$, based on the annual-layer counting reported here. This evaluation was also undertaken for the onset of the GI-21 precursor warming and corresponding $\mathrm{CH}_{4}$ concentration increase, as shown in Fig. 4, and found to have a $\Delta$ age range of 523 to $654 \mathrm{yr}$. These calculated $\Delta$ age ranges are comparable to those employed by Capron et al. (2010b) in their NGRIP-EDML synchronization, as reported in their Fig. 5. Figure 4 also shows the relative phasing of $\delta^{15} \mathrm{~N}$ and $\mathrm{CH}_{4}$ at the onset of GI-21, between NGRIP depths of $2693.3 \mathrm{~m}$ (latest possible $\mathrm{CH}_{4}$ increase) and $2693.9 \mathrm{~m}$ (earliest possible $\delta^{15} \mathrm{~N}$ increase). The annual-layer counted chronology presented here shows that the maximum possible difference between $\delta^{15} \mathrm{~N}$ and $\mathrm{CH}_{4}$ is $69 \pm 5 \mathrm{yr}$, although the difference is most likely on the order of a few decades, consistent with the range of 25 to $70 \mathrm{yr}$ proposed by Huber et al. (2006).

Our revision of the duration of GS-22 gives further support to the thermal bipolar seesaw theory of heat exchange between the Northern and Southern Hemispheres via oceanic circulation. Adapted from Capron et al. (2010a), Fig. 5 displays a strong correlation between the duration of Greenland cooling (GS duration) and the amplitude of Antarctic warming (temperature change during AIM events) for most of the past glacial period. The relationship is an empirical confirmation of the thermal bipolar seesaw model proposed by Stocker and Johnsen (2003) although it is apparent that GS-3, 19 and 22 are outliers from this relationship. It is of interest to note that the duration of GS-22 is only consistent with the linear fit in Fig. 5 if the duration of the GI-21 precursor period is not included. This suggests that the trigger of accelerating Atlantic meridional overturning circulation and associated heat transport from the Southern Ocean to the North Atlantic may lie with the climatic reorganization occurring during the precursor event, rather than that of the following GI onset. In summary, our findings suggest that the thermal capacity of the Southern Ocean heat reservoir is not exhausted during longer stadials such as GS-22 and instead implies that other climatic processes may have been responsible for the unexpectedly slight warmings of Antarctica during GS-3 and GS-19.

\section{Conclusions}

The development of a high-resolution CFA system has enabled the identification of thin $(<1 \mathrm{~cm})$ annual layers in early glacial ice from the Greenland NGRIP ice core. We demonstrate that during GS-22 the annual layer thickness $\lambda$ calculated by the $s \mathrm{~s} 09 \mathrm{sea} 06 \mathrm{bm}$ model is overestimated by approximately $10 \%$, indicating a need to revise this section (including GIs 21 and 22) of the GICC05modelext chronology. The revised GS-22 duration presented here is not consistent with the gas-synchronized NGRIP-EDML chronology although it does agree with that of an independent U-Th dated speleothem record from the Northern Alps. Our proposed GS-22 duration is consistent with a strong correlation between GS duration and Antarctic warming as proposed by Stocker and Johnsen (2003). These findings suggest that the EDML chronology may need to be revised in the time period corresponding to GS-22. This work opens the possibility for annual layer counting in other polar ice cores for which absolute chronological markers are lacking. The combination of these data with high-resolution gas measurements in NGRIP will also help to constrain the $\Delta$ age relationship in the ice core, thus allowing ice flow models and understanding of firn densification processes to be improved.

Acknowledgements. We thank Bo Vinther, Emelie Capron, Amaelle Landais and Myriam Guillevic for helpful discussions. This work is a contribution to the NorthGRIP ice core project, which is directed and organized by the Centre for Ice and Climate at the Niels Bohr Institute, University of Copenhagen. It is being supported by funding agencies in Denmark (SNF/FNU), Belgium (FNRS-CFB), France (IFRTP and INSU/CNRS), Germany (AWI), Iceland (RannIs), Japan (MEXT), Sweden (SPRS), Switzerland (SNF) and the United States of America (NSF).

Edited by: E. Brook

\section{References}

Andersen, K. K., Svensson, A., Rasmussen, S. O., Steffensen, J. P., Johnsen, S. J., Bigler, M., Röthlisberger, R., Ruth, U., SiggaardAndersen, M.-L., Dahl-Jensen, D., Vinther, B. M., and Clausen, H. B.: The Greenland Ice Core Chronology 2005, 15-42 ka. Part 1: constructing the time scale, Quaternary Sci. Rev., 25, 32463257, doi:10.1016/j.quascirev.2006.08.002, 2006.

Bender, M., Sowers, T., Dickson, M.-L., Orchardo, J., Grootes, P., Mayewski, P. A., and Meese, D. A.: Climate correlations between Greenland and Antarctica during the last 100,000 years, Nature, 372, 663-666, doi:10.1038/372663a0, 1994.

Bigler, M.: Hochauflösende Spurenstoffmessungen an polaren Eisbohrkernen: Glazio-chemische und klimatische Prozessstudien, Physics Institute, University of Bern, Switzerland, 2004.

Bigler, M., Svensson, A., Kettner, E., Vallelonga, P., Nielsen, M., and Steffensen, J. P.: Optimization of High-Resolution Continuous Flow Analysis for Transient Climate Signals in Ice Cores, 
Environ. Sci. Technol., 45, 4483-4489, doi:10.1021/es200118j, 2011.

Blunier, T. and Brook, E. J.: Timing of millennial-scale climate change in Antarctica and Greenland during the last glacial period, Science, 291, 109-112, doi:10.1126/science.291.5501.109, 2001.

Boch, R., Cheng, H., Spötl, C., Edwards, R. L., Wang, X., and Häuselmann, Ph.: NALPS: a precisely dated European climate record 120-60 ka, Clim. Past, 7, 1247-1259, doi:10.5194/cp-71247-2011, 2011.

Capron, E., Landais, A., Chappellaz, J., Schilt, A., Buiron, D., Dahl-Jensen, D., Johnsen, S. J., Jouzel, J., Lemieux-Dudon, B., Loulergue, L., Leuenberger, M., Masson-Delmotte, V., Meyer, H., Oerter, H., and Stenni, B.: Millennial and sub-millennial scale climatic variations recorded in polar ice cores over the last glacial period, Clim. Past, 6, 345-365, doi:10.5194/cp-6-3452010, 2010a.

Capron, E., Landais, A., Lemieux-Dudon, B., Schilt, A., MassonDelmotte, V., Buiron, D., Chappellaz, J., Dahl-Jensen, D., Johnsen, S., Leuenberger, M., Loulergue, L., and Oerter, H.: Synchronising EDML and NorthGRIP ice cores using $\delta^{18} \mathrm{O}$ of atmospheric oxygen $\left(\delta^{18} \mathrm{O}_{\mathrm{atm}}\right)$ and $\mathrm{CH}_{4}$ measurements over MIS5 (80-123 kyr), Quaternary Sci. Rev., 29, 222-234, doi:10.1016/j.quascirev.2009.07.014, 2010b.

EPICA community members: One-to-one coupling of glacial climate variability in Greeland and Antartctica, Nature, 444, 195198, doi:10.1038/nature05301, 2006.

Gkinis, V., Popp, T. J., Johnsen, S. J., and Blunier, T.: A continuous stream flash evaporator for the calibration of an IR cavity ring-down spectrometer for the isotopic analysis of water, Isot. Environ. Healt. S., 46, 463-475, doi:10.1080/10256016.2010.538052, 2010.

Gkinis, V., Popp, T. J., Blunier, T., Bigler, M., Schüpbach, S., Kettner, E., and Johnsen, S. J.: Water isotopic ratios from a continuously melted ice core sample, Atmos. Meas. Tech., 4, 25312542, doi:10.5194/amt-4-2531-2011, 2011.

Grachev, A. M., Brook, E. J., and Severinghaus, J. P.: Abrupt changes in atmospheric methane at the MIS 5b-5a transition, Geophys. Res. Lett., 34, L20703, doi:10.1029/2007GL029799, 2007.

Hörhold, M. W., Laepple, T., Freitag, J., Bigler, M., Fischer, H., and Kipfstuhl, S.: On the impact of impurities on the densification of polar firn, Earth Planet. Sc. Lett., 325-326, 93-99, doi:10.1016/j.epsl.2011.12.022, 2012.

Huber, C., Leuenberger, M., Spahni, R., Flückiger, J., Schwander, J., Stocker, T. F., Johnsen, S., Landais, A., and Jouzel, J.: Isotope calibrated Greenland temperature record over Marine Isotope Stage 3 and its relation to $\mathrm{CH}_{4}$, Earth Planet. Sc. Lett., 243, 504-519, doi:10.1016/j.eps1.2006.01.002, 2006.

Johnsen, S. J., DahlJensen, D., Gundestrup, N., Steffensen, J. P., Clausen, H. B., Miller, H., Masson-Delmotte, V., Sveinbjornsdottir, A. E., and White, J.: Oxygen isotope and palaeotemperature records from six Greenland ice-core stations: Camp Century, Dye-3, GRIP, GISP2, Renland and NorthGRIP, J. Quaternary Sci., 16, 299-307, 2001.

Kaufmann, P., Federer, U., Hutterli, M. A., Bigler, M., Schüpbach, S., Ruth, U., Schmitt, J., and Stocker, T. F.: An improved continuous flow analysis system for high-resolution field measurements on ice cores, Environ. Sci. Technol., 42, 8044-8050, doi:10.1021/es8007722, 2008.

Landais, A., Masson-Delmotte, V., Jouzel, J., Raynaud, D., Johnsen, S., Huber, C., Leuenberger, M., Schwander, J., and Minster, B.: The glacial inception as recorded in the NorthGRIP Greenland ice core: Timing, structure and associated abrupt temperature changes, Clim. Dynam., 26, 273-284, doi:10.1007/s00382-0050063-y, 2006.

Lemieux-Dudon, B., Blayo, E., Petit, J. R., Waelbroeck, C., Svensson, A., Ritz, C., Barnola, J. M., Narcisi, B., and Parrenin, F.: Consistent dating for Antarctic and Greenland ice cores, Quaternary Sci. Rev., 29, 8-20, doi:10.1016/j.quascirev.2009.11.010, 2010.

Mayewski, P. A., Meeker, L. D., Twickler, M. S., Whitlow, S., Yang, Q. Z., Lyons, W. B., and Prentice, M.: Major features and forcing of high-latitude northern hemisphere atmospheric circulation using a 110,000-year-long glaciochemical series, J. Geophys. Res., 102, 26345-26366, doi:10.1029/96JC03365, 1997.

Moore, J. C., Wolff, E. W., Clausen, H. B., Hammer, C. U., Legrand, M. R., and Fuhrer, K.: Electrical response of the SummitGreenland ice core to ammonium, sulphuric acid, and hydrochloric acid, Geophys. Res. Lett., 21, 565-568, 1994.

NGRIP members: High-resolution record of Northern Hemisphere climate extending into the last interglacial period, Nature, 431, 147-151, doi:10.1038/nature02805, 2004.

Parrenin, F., Petit, J.-R., Masson-Delmotte, V., Wolff, E., BasileDoelsch, I., Jouzel, J., Lipenkov, V., Rasmussen, S. O., Schwander, J., Severi, M., Udisti, R., Veres, D., and Vinther, B. M.: Volcanic synchronisation between the EPICA Dome $\mathrm{C}$ and Vostok ice cores (Antarctica) 0-145 kyr BP, Clim. Past, 8, 1031-1045, doi:10.5194/cp-8-1031-2012, 2012.

Rasmussen, S. O., Seierstad, I. K., Andersen, K. K., Bigler, M., Dahl-Jensen, D., and Johnsen, S. J.: Synchronization of the NGRIP, GRIP, and GISP2 ice cores across MIS 2 and palaeoclimatic implications, Quaternary Sci. Rev., 27, 18-28, doi:10.1016/j.quascirev.2007.01.016, 2008.

Röthlisberger, R., Bigler, M., Hutterli, M. A., Sommer, S., Stauffer, B., Junghans, H. G., and Wagenbach, D.: Technique for Continuous High-Resolution Analysis of Trace Substances in Firn and Ice Cores, Environ. Sci. Technol., 34, 338-342, doi:10.1021/es9907055, 2000.

Ruth, U., Wagenbach, D., Bigler, M., Steffensen, J. P., Röthlisberger, R., and Miller, H.: High resolution microparticle profiles at NGRIP: Case studies of calcium-dust relationship, Ann. Glaciol., 35, 237-242, 2002.

Salamatin, A. N., Lipenkov, V. Y., Barnola, J. M., Hori, A., Duval, P., and Hondoh, T.: Snow/firn densification in polar ice sheets, in: Physics of Ice Core Records II : Papers collected after the 2nd International Workshop on Physics of Ice Core Records, held in Sapporo, Japan, 2-6 February 2007, edited by: Hondoh, T., Institute of Low Temperature Science, Hokkaido University, Sapporo, 195-222, 2009.

Severinghaus, J. P., Sowers, T., Brook, E. J., Alley, R. B., and Bender, M. L.: Timing of abrupt climate change at the end of the Younger Dryas interval from thermally fractionated gases in polar ice, Nature, 391, 141-146, doi:10.1038/34346, 1998.

Steffensen, J. P., Andersen, K. K., Bigler, M., Clausen, H. B., DahlJensen, D., Fischer, H., Goto-Azuma, K., Hansson, M., Johnsen, S. J., Jouzel, J., Masson-Delmotte, V., Popp, T., Rasmussen, S. O., Röthlisberger, R., Ruth, U., Stauffer, B., Siggaard-Andersen, 
M.-L., Sveinbjörnsdóttir, Á. E., Svensson, A., and White, J. W. C.: High-Resolution Greenland Ice Core Data Show Abrupt Climate Change Happens in Few Years, Science, 321, 680-684, doi:10.1126/science.1157707, 2008.

Stocker, T. F. and Johnsen, S. J.: A minimum thermodynamic model for the bipolar seesaw, Paleoceanography, 18, 1087, doi:10.1029/2003PA000920, 2003.

Stowasser, C., Buizert, C., Gkinis, V., Chappellaz, J., Schüpbach, S., Bigler, M., Faïn, X., Sperlich, P., Baumgartner, M., Schilt, A., and Blunier, T.: Continuous measurements of methane mixing ratios from ice cores, Atmos. Meas. Tech., 5, 999-1013, doi:10.5194/amt-5-999-2012, 2012.

Svensson, A., Nielsen, S. W., Kipfstuhl, S., Johnsen, S. J., Steffensen, J. P., Bigler, M., Ruth, U., and Röthlisberger, R.: Visual stratigraphy of the North Greenland Ice Core Project (NorthGRIP) ice core during the last glacial period, J. Geophys. Res., 110, D02108, doi:10.1029/2004JD005134, 2005.

Svensson, A., Andersen, K. K., Bigler, M., Clausen, H. B., DahlJensen, D., Davies, S. M., Johnsen, S. J., Muscheler, R., Parrenin, F., Rasmussen, S. O., Röthlisberger, R., Seierstad, I., Steffensen, J. P., and Vinther, B. M.: A 60000 year Greenland stratigraphic ice core chronology, Clim. Past, 4, 47-57, doi:10.5194/cp-4-472008, 2008.
Svensson, A., Bigler, M., Kettner, E., Dahl-Jensen, D., Johnsen, S., Kipfstuhl, S., Nielsen, M., and Steffensen, J. P.: Annual layering in the NGRIP ice core during the Eemian, Clim. Past, 7, 1427 1437, doi:10.5194/cp-7-1427-2011, 2011.

Thomas, E. R., Wolff, E. W., Mulvaney, R., Johnsen, S. J., Steffensen, J. P., and Arrowsmith, C.: Anatomy of a DansgaardOeschger warming transition: High-resolution analysis of the North Greenland Ice Core Project ice core, J. Geophys. Res., 114, D08102, doi:10.1029/2008JD011215, 2009.

Wang, Y., Cheng, H., Edwards, R. L., Kong, X., Shao, X., Chen, S., Wu, J., Jiang, X., Wang, X., and An, Z. Millennial- and orbital-scale changes in the East Asian monsoon over the past 224,000 years, Nature, 451, 1090-1093, doi:10.1038/nature06692, 2008.

Wolff, E. W., Chappellaz, J., Blunier, T., Rasmussen, S. O., and Svensson, A.: Millennial-scale variability during the last glacial: The ice core record, Quaternary Sci. Rev., 29, 2828-2838, doi:10.1016/j.quascirev.2009.10.013, 2010. 